\title{
STATISTICAL EVALUATION OF RESULTS OF PROFILE GDOES ANALYSIS OF GALVANIZED SHEET METAL
}

\author{
${ }^{1}$ Jiřina VONTOROVÁ, ${ }^{1}$ Petra VÁŇOVÁ, ${ }^{1}$ Karolina SLAMOVÁ \\ ${ }^{1}$ VSB - Technical University of Ostrava, Ostrava, Czech Republic, EU, jirina.vontorova@vsb.cz
}

https://doi.org/10.37904/metal.2021.4199

\begin{abstract}
Galvanizing still plays an important role in surface treatments. The thickness and quality of the zinc layer is the basic monitored property of materials treated in this way. Optical microscopy gives the correct value of the layer thickness, but it is a time-consuming destructive method. Conversely, GDOES is a fast method, but its accuracy needs to be verified (e.g. microscopically). This article also deals with another important parameter of the method (accuracy and thus also the repeatability of measurements). It follows that the GDOES method is correct and accurate for measuring the thickness of the zinc layer.
\end{abstract}

Keywords: Zn layer, GDOES, optical microscopy, accuracy, precision

\section{INTRODUCTION}

The automotive industry is an important sector of mechanical engineering and places great emphasis on the development of new materials and technological processes and monitoring the quality of processes, products, and raw materials. All car manufacturers use coated materials in the manufacture of the body. The main task of surface engineering is to provide corrosion protection, which increases the product life of the product and modifies its external appearance [1,2]. One of the most frequently used anti-corrosion treatments is galvanizing.

The appearance and properties of Zn coatings depend on the preparation technology. Zinc [3] is applied to steel products by five basic processes [4]: galvanizing, hot-dip galvanizing (metallization), hot-dip galvanizing in molten zinc [5], mechanical galvanizing, and sherardizing (diffusion galvanizing). This article deals with the determination of the thickness of a galvanically prepared $\mathrm{Zn}$ layer.

Statistical data evaluation plays an important role in analytical chemistry [6]. Especially with a large number of measurements, it is absolutely necessary to evaluate the data on the basis of knowledge of chemometric procedures [7]. It is necessary to confirm or refute the normality of the data (Gaussian distribution) and to evaluate the characteristics of position and variability and the accuracy and precision of analyses on the basis of exploratory and statistical analysis [8].

The accuracy of the analytical method is tested using reference materials or methods. The test of the correctness of the method consists in verifying the statistical significance of the difference between the average result and the correct value of $\mu_{0}$. For larger selections of values $n>10$ ), the Student's t-test is used to test of the correctness of selection: $t=\frac{\left|\bar{x}-\mu_{0}\right|}{s} \sqrt{n}$. The calculated $t$-characteristic is compared with the tabulated critical value $t_{1-\alpha / 2 ;}$, where $v$ is the number of degrees of freedom $v=n-1$ ) If it is less than the critical value $t_{1-\alpha / 2 ; v}$ the difference between the mean and the correct value is statistically insignificant, and, therefore, the mean is correct - the method gives correct results. 


\section{EXPERIMENTAL MATERIAL}

Galvanized sheet metal without final surface treatment was used for statistical evaluation of repeatability of $\mathrm{Zn}$ layer thickness determination using GDOES profile analysis (see Figure 1). The chemical composition of the base material is given in Table 1. It is IF (Interstitial Free) steel, which is standardly used in the automotive industry, especially for the production of the most exposed body parts, such as bumpers, wings, doors, hood, trunk lid, and roof.

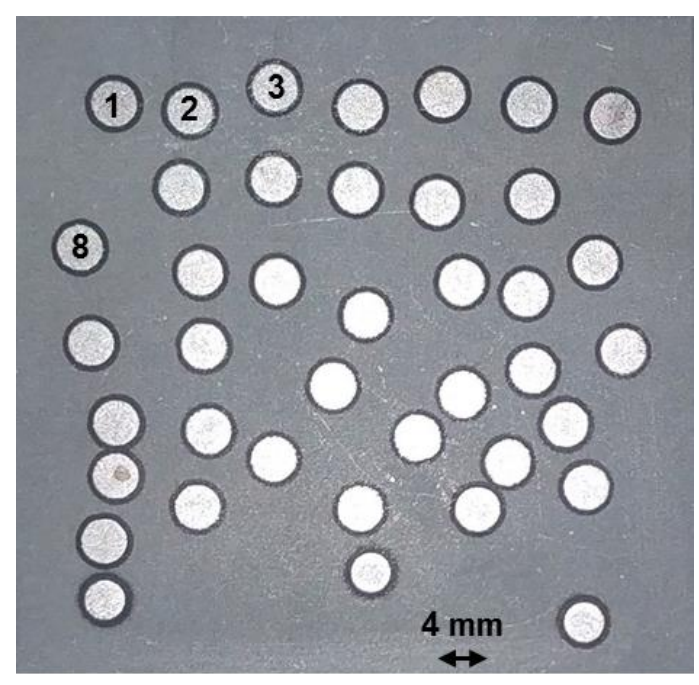

Figure 1 Galvanized sheet metal with craters after GDOES profile analysis

Table 1 Chemical composition of the base material (wt.\%)

\begin{tabular}{|c|c|c|c|c|c|c|c|}
\hline $\mathbf{C}$ & $\mathbf{M n}$ & $\mathbf{S i}$ & $\mathbf{P}$ & $\mathbf{S}$ & $\mathbf{C r}$ & $\mathbf{~ N i}$ & Mo \\
\hline 0.008 & 0.338 & 0.011 & 0.016 & 0.006 & 0.052 & 0.047 & 0.012 \\
\hline $\mathbf{C u}$ & $\mathbf{T i}$ & $\mathbf{C o}$ & $\mathbf{B}$ & $\mathbf{P b}$ & $\mathbf{V}$ & $\mathbf{W}$ & $\mathbf{A l}$ \\
\hline \multicolumn{7}{|c|}{ wt. \% } \\
\hline 0.034 & $<0.001$ & $<0.001$ & $<0.0001$ & $<0.001$ & 0.011 & $<0.001$ & 0.032 \\
\hline
\end{tabular}

The thickness of the zinc coating was determined by optical microscopy. The following figure is a crosssectional image of the zinc layer on the sample (Figure 2).

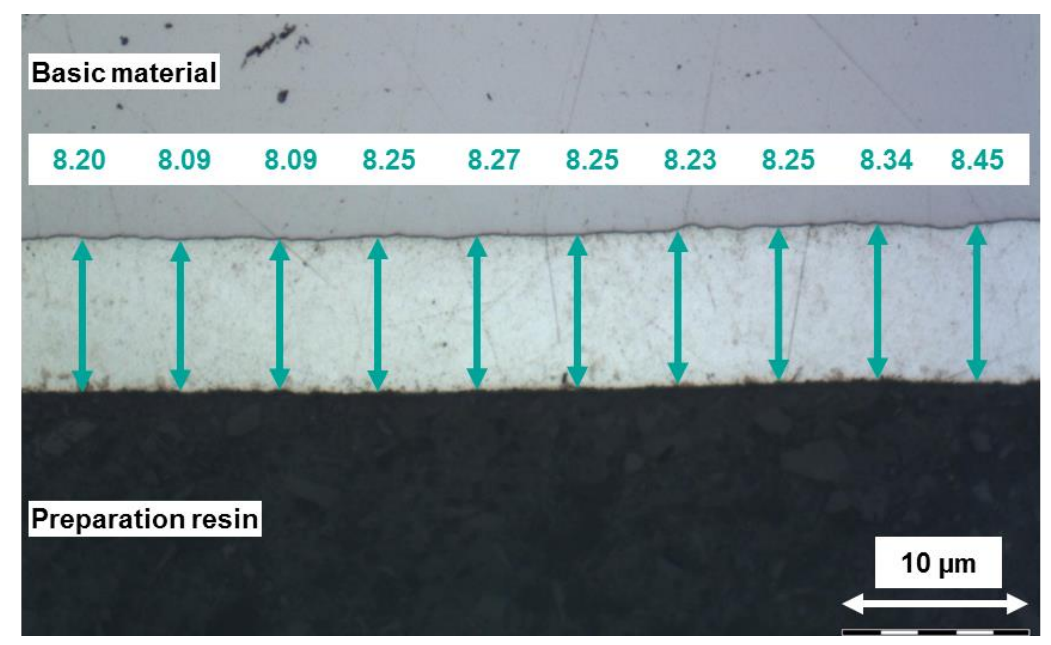

Figure 2 Zn layer - in cross section on an Olympus IX70 optical microscope 


\section{EXPERIMENTAL METHODS}

An optical emission spectrometer with a glow discharge Spectruma Analytik GMBH (model GDA 750) was used in this work. The average chemical composition of the base material of the samples was determined by BULK GDOES analysis under excitation conditions of $700 \mathrm{~V}$ and $35 \mathrm{~mA}[9,10]$. The profile analysis was performed under excitation conditions of $1000 \mathrm{~V}$ and $15 \mathrm{~mA}$. Profile GDOES is used for evaluation of quality and thickness of hot-dip galvanized coating [5], cobalt alloy films [11], organic substances [12], and materials with non-conductive surfaces using a radio-frequency source (RF-GDOES) [13].

The measurement of the thickness of the zinc layer on the sample was performed in a cross section on an Olympus IX50 optical microscope [14,15]. Both devices are operated at the Faculty of Materials Science and Technology, VŠB - Technical University of Ostrava.

\section{RESULTS AND DISCUSSION}

Optical microscopy is an objective method for determining the thickness of a zinc layer (see Figure 2). This was measured at 10 metallographic sections, and the sample thus obtained was also statistically evaluated. First, the sign test confirmed the independence of the data, then the presence of outlying data was ruled out using a histogram constructed using MS Excel (Figure 3), and the normality was confirmed. The same conclusion was obtained by evaluating the data in the QC-Expert software.

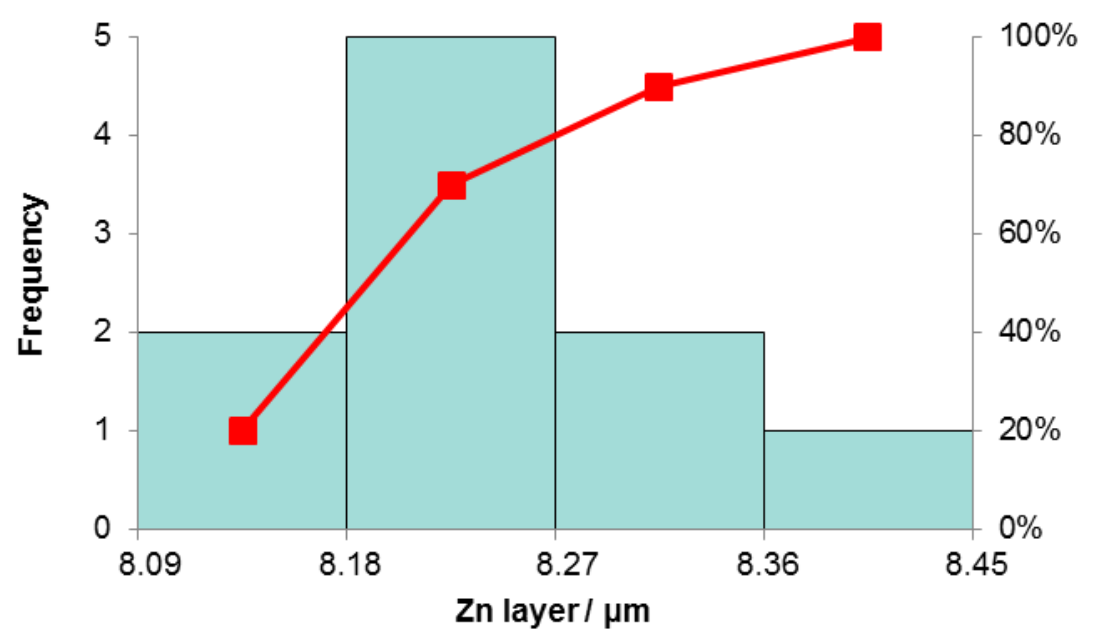

Figure 3 Histogram (MS Excel) - assessment of a selected set of data from optical microscopy

Due to the low number of data, one-dimensional analysis was performed according to Horn's method [6]. The pivot half-sum (characterized by the mean value) has a value of $8.239 \mu \mathrm{m}$, and the $95 \%$ interval of the mean value is $8.193<\mu<8.284$. The characteristics calculated by the Horn method do not differ much from the moment characteristics (mean $=8.242 \mu \mathrm{m}$; standard deviation $=0.106 \mu \mathrm{m}$ ). The slope of this selection is 0.278 , and the slope is 2.91 , which supports the result of the normality test - that is, the Gaussian distribution. Data homogeneity was also confirmed.

The repeatability of the profile GDOES analysis was verified by 40 measurements of the $\mathrm{Zn}$ layer thickness (see Figure 1) under identical conditions. The following figure (Figure 4) shows, for example, 4 records of the profile GDOES analysis of galvanized sheet metal (the analysis number is marked in Figure 1).

Figure 4 shows profile records of iron, zinc, carbon, manganese, sulfur, chromium and nickel. Other elements have such a low percentage that their display would not make sense. The scales of the profile records of 
carbon, manganese, sulfur, chromium and nickel also had to be changed for the sake of recognisability - the value read from the record must be multiplied by one hundred - as can be seen from the legends of the records.
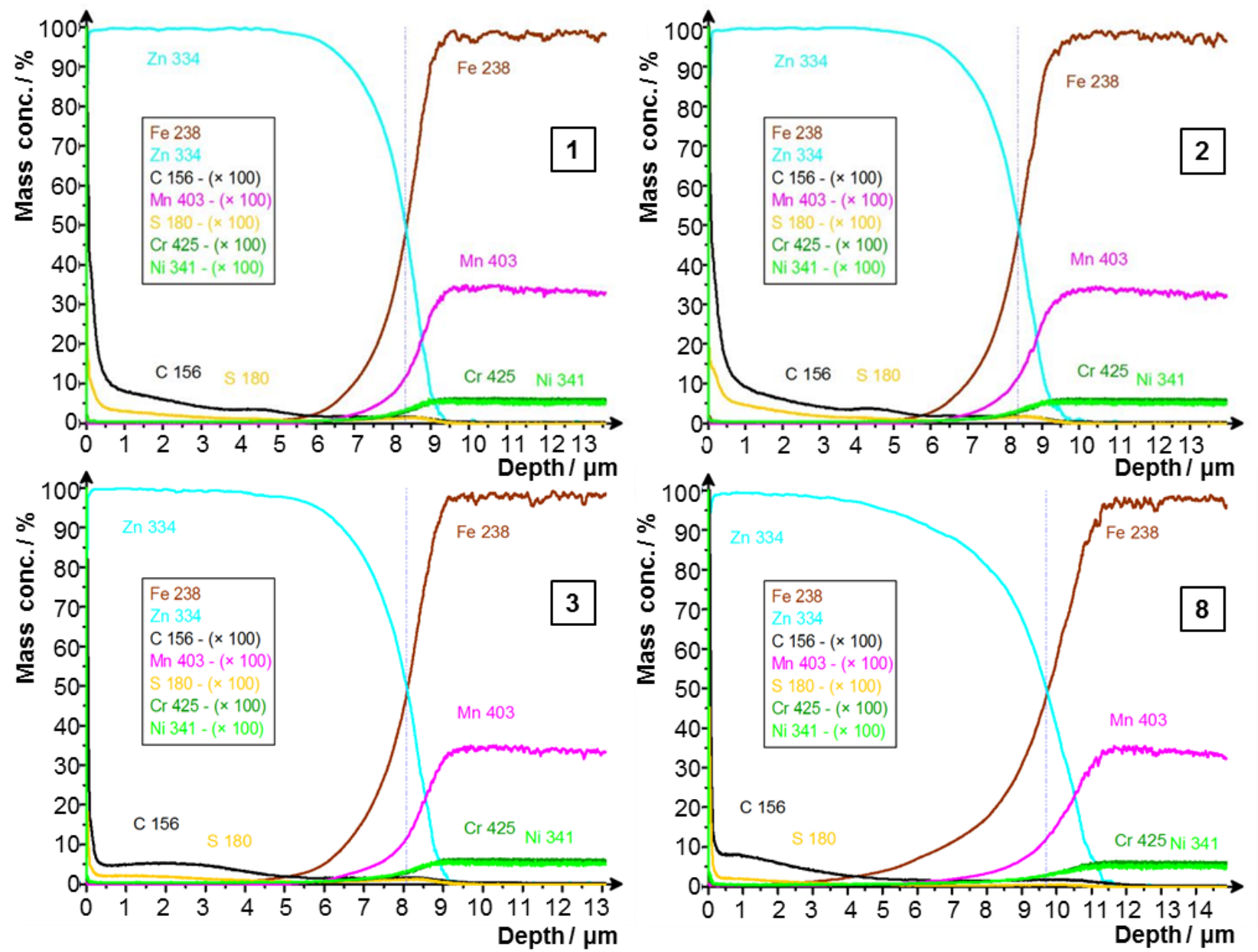

Figure 4 Records of profile GDOES analyses of galvanized sheet - analyses No. 1, 2, 3, 8

The record of analyses 1-3 shows that a layer of pure $\mathrm{Zn}$ occurs up to a depth of about $5 \mu \mathrm{m}$. Then there is a "mixed" region of $\mathrm{Zn}$ and the parent metal, and from a depth of about $9.5 \mu \mathrm{m}, \mathrm{Zn}$ no longer occurs. In Figure 4 - Analysis 8, the course of the analysis is different. There is a gradual decrease of $\mathrm{Zn}$ from $3 \mu \mathrm{m}$, and the base metal occurs up to a depth of $12 \mu \mathrm{m}$. However, this is the only spectrum with such a course, so it is advisable to consider omitting it from the basic data set.

There is also a carbon and sulfur line in the range of 0 to $5 \mu \mathrm{m}$ (about $0.05 \% \mathrm{C}$ and $0.01 \% \mathrm{~S}$ ). This may be due to surface dirt, or more likely to the instability of the photomultipliers at the beginning of the measurement.

Quantitative evaluation of all analyses is summarized in Table 2. For illustrative comparison, the thickness at which the $\mathrm{Zn}$ layer is considered to be the thickness at which the zinc and iron profile lines cross (indicated by a vertical dashed line in the records in Figure 4).

All data from Table 2 were assessed as a source file using QC-Expert software. The independence of the data was verified, and the homogeneity of the data was assessed using exploratory analysis. One of the most common ways to graph data is a box graph (Figure 5a). It allows the representation of a robust estimate of the position - median, assessment of the symmetry of the distribution, and especially the identification of suspected outliers measurements. According to the above graph, one value is suspected of being outliers because it lies outside the "lengths of the lines" (measurement No. 8). This conclusion was 
confirmed using all graphical and numerical tests of QC-Expert software. Therefore, this outlier was omitted from the set and the exploratory analysis was performed again (see Figure 5b).

Table $2 \mathrm{Zn}$ layer thicknesses determined by GDOES profile analysis

\begin{tabular}{|c|c|c|c|c|c|c|c|c|c|c|}
\hline Analysis No. & $\mathbf{1}$ & $\mathbf{2}$ & $\mathbf{3}$ & $\mathbf{4}$ & $\mathbf{5}$ & $\mathbf{6}$ & $\mathbf{7}$ & $\mathbf{8}$ & $\mathbf{9}$ & $\mathbf{1 0}$ \\
\hline thickness of Zn layer / $\mathbf{\mu m}$ & 8.4 & 8.4 & 8.1 & 8.2 & 8.3 & 8.1 & 8.4 & 9.7 & 8.5 & 8.4 \\
\hline Analysis No. & $\mathbf{1 1}$ & $\mathbf{1 2}$ & $\mathbf{1 3}$ & $\mathbf{1 4}$ & $\mathbf{1 5}$ & $\mathbf{1 6}$ & $\mathbf{1 7}$ & $\mathbf{1 8}$ & $\mathbf{1 9}$ & $\mathbf{2 0}$ \\
\hline thickness of Zn layer / $\mathbf{\mu m}$ & 8.3 & 8.4 & 8.2 & 8.4 & 8.0 & 8.2 & 8.1 & 8.4 & 7.9 & 8.5 \\
\hline Analysis No. & $\mathbf{2 1}$ & $\mathbf{2 2}$ & $\mathbf{2 3}$ & $\mathbf{2 4}$ & $\mathbf{2 5}$ & $\mathbf{2 6}$ & $\mathbf{2 7}$ & $\mathbf{2 8}$ & $\mathbf{2 9}$ & $\mathbf{3 0}$ \\
\hline thickness of Zn layer / $\mathbf{\mu m}$ & 8.3 & 8.4 & 8.0 & 8.6 & 8.5 & 7.9 & 8.1 & 8.3 & 8.4 & 8.4 \\
\hline Analysis No. & $\mathbf{3 1}$ & $\mathbf{3 2}$ & $\mathbf{3 3}$ & $\mathbf{3 4}$ & $\mathbf{3 5}$ & $\mathbf{3 6}$ & $\mathbf{3 7}$ & $\mathbf{3 8}$ & $\mathbf{3 9}$ & $\mathbf{4 0}$ \\
\hline thickness of Zn layer / $\mathbf{\mu m}$ & 8.3 & 8.0 & 8.5 & 8.1 & 8.2 & 8.1 & 8.4 & 8.6 & 8.4 & 8.4 \\
\hline
\end{tabular}

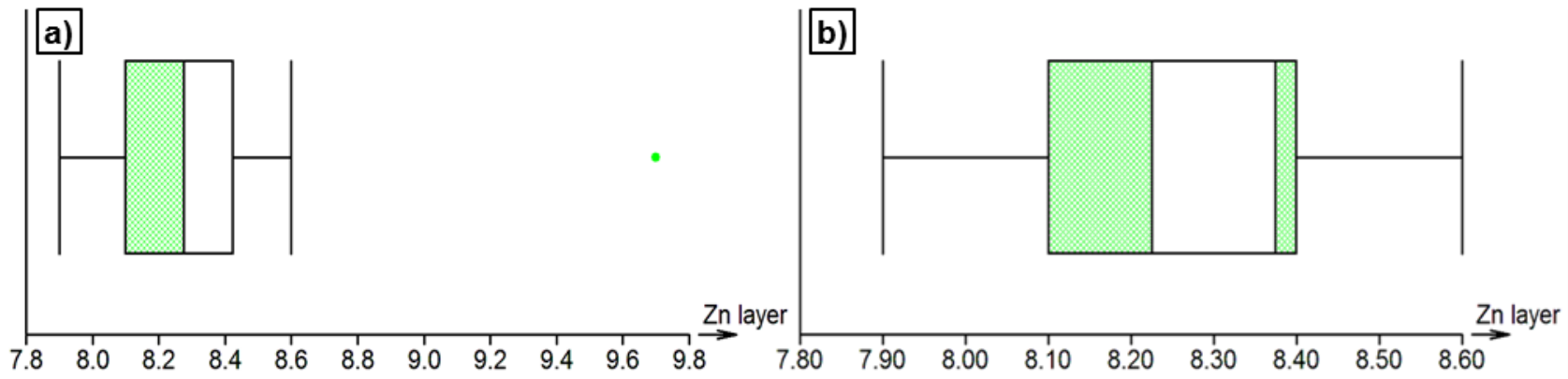

Figure 5 Box chart (QC-Expert): a) whole selection; b) selection after omitting an outlier

Based on the exploratory analysis, it can be said that the sample of data is independent (based on the sign test), is homogeneous, and has a Gaussian and symmetric distribution (skewness $=-0.409$; kurtosis $=2.231)$. Therefore, it is most appropriate to use the moment characteristics of position and variability $($ mean $=8.285 \mu \mathrm{m}$, standard deviation $=0.187 \mu \mathrm{m})$ to describe the selection.

The accuracy of the profile GDOES analysis was tested at the significance level $\alpha=0.05$ using Student's t-test: $t=\frac{\left|\bar{x}-\mu_{0}\right|}{s} \sqrt{n}$. The calculated $t$-characteristic (from the values in Table 2) was compared with the tabulated critical value $t_{1-\alpha / 2 ;}$, where $v$ is the number of degrees of freedom $(v=n-1=39-1=38)$. Since for the parameters $t=1.522$ and $t_{0.975 ; 38}=2.02$, it holds that $t<t_{0,975 ; 38}$ it can be stated that the GDOES method gives correct results with $95 \%$ probability.

\section{CONCLUSION}

The task of this work was to verify whether GDOES profile analysis gives correct and accurate results. 40 analyses were performed on a galvanized IF sheet. One outlier was identified using exploratory analysis. After its omission from the set, the homogeneity, independence, and normality of the data were confirmed. Due to the low standard deviation and the narrow confidence interval, the GDOES method can be considered accurate.

Optical microscopy was chosen as a reference method to verify the accuracy of the data. The thickness of the $\mathrm{Zn}$ layer was determined on a metallographic section, and using statistical analysis (Student's t-test), it was found that there is no statistical difference between the results with $95 \%$ probability. 


\section{ACKNOWLEDGEMENTS}

This work was solved within the frame of project No. SS01020312 "Innovative technology of the closed loop water circulation in the electro-galvanizing process and processing of metal waste sludges and filtration cakes from the galvanizing plant" and was supported by VŠB-Technical University of Ostrava: SP2021/41, SP2021/48 and SP2021/46.

\section{REFERENCES}

[1] PODJUKLOVÁ, J., SUCHÁNKOVÁ, K., ŠRUBAR, P., KOPANAKOVÁ, S., HRABOVSKÁ, K. Study of influence corrosive environment on characteristics protective coatings used for long-term corrosion protection of steel substrate. In: METAL 2013: 22nd International Conference on Metallurgy and Materials. Ostrava: TANGER, 2013, pp. 953-958. WOS: 000333163100156

[2] PODJUKLOVÁ, J. Speciální technologie povrchových úprav I. Učební texty. VŠB - TUO, Ostrava, 1997, 71 s. ISBN 80-8778-235-8

[3] BROŽOVÁ, S., DRÁPALA, J., KURSA, M., PUSTĚJOVSKÁ, P., JURSOVÁ, S. Leaching refuse after sphalerite mineral for extraction zinc and cobalt. Metalurgija. 2016, vol. 55, no. 3, p. 497-499. WOS:000372344500054

[4] KUKLíK, V., KUDLÁČEK, J. Hot-Dip galvanizing of steel structures. Elsevier Inc., 2016.

[5] VONTOROVÁ, J., MOHYLA, P. Use of GDOES method for evaluation of the quality and thickness of hot dip galvanised coating. Transactions of the Institute of Metal Finishing. [online]. 2018, vol. 96, no. 6, pp. 313-318. Available from: https://doi.org/10.1080/00202967.2018.1520531.

[6] MELOUN, M., MILITKÝ, J. Statistical data analysis: A practical guide. Woodhead Publishing Limited, 2011.

[7] KLIKA, Z., SERENČIŠOVÁ, J., KOŽUŠNÍKOVÁ, A., KOLOMAZNíK, I., STUDENTOVÁ, S., VONTOROVÁ, J. Multivariate statistical assessment of coal properties. Fuel Processing Technology. 2014, 128, pp. 119-127. WOS: 000343389900014.

[8] MELOUN, M., MILITKÝ, J. Kompendium statistického zpracování dat. Praha: Karolinum, 2012, p. 985.

[9] VONTOROVÁ, J., VÁŇOVÁ, P. Determination of carburized layer thickness by GDOES method. AIMS Materials Science. 2018, vol. 5, no. 1, pp. 34-43. WOS:000428531900002

[10] MOHYLA, P., HAJNYS, J., STERNADELOVÁ, K., KREJČí, L., PAGÁČ, M., KONEČNÁ, K., KRPEC, P. Analysis of Welded Joint Properties on an AISI316L Stainless Steel Tube Manufactured by SLM Technology. Materials. [online]. 2020, vol. 13, no. 19. Available from: https://doi.org/10.3390/ma13194362.

[11] FUKUMURO, N., NISHIYAMA, J., SHIGETA, K., TAKAGAMI, H., YAE, S. and MATSUDA, H. Confirmation of hydroxide in electroless cobalt alloy films by GDOES. Transactions of the IMF. 2013, vol. 85, no. 2, pp. 111-112.

[12] LIU, Y., JIAN, W., WANG, J.Y., HOFMANN, S. and SHIMIZU, K. (2015). Quantitative reconstruction of the GDOES sputter depth profile of a monomolecular layer structure of thiourea on copper. Applied Surface Science. [online]. 2015, vol. 331, pp. 140-149. Available from: https://doi.org/10.1016/i.apsusc.2015.01.065.

[13] ESCOBAR GALINDO, R., FORNIÉS, E. and ALBELLA, J.M. Compositional depth profiling analysis of thin and ultrathin multilayer coatings by radio-frequency glow discharge optical emission spectroscopy. Surface and Coatings Technology. [online]. 2006, vol. 200, no. 22-23, pp. 6185-6189. Available from: https://doi.org/10.1016/i.surfcoat.2005.11.064.

[14] MOHYLA, P., FOLDYNOVA, K. Effect of Post-Welding Heat Treatment on Mechanical Properties of Joints of Steel P92 Formed by Submerged Arc Welding. In: Metal Science and Heat Treatment. [online]. Springer, 2014, vol. 56, No. 3-4, pp: 206-209. Available from: https://doi.org/10.1007/s11041-014-9732-y.

[15] STERNADELOVÁ, K., MOHYLA, P., TROMBIK, M., KRUPOVÁ, H. Properties and microstructure of modeled heat-affected zone of P92 steel. In: METAL 2019: 28th International Conference on Metallurgy and Materials. Ostrava: Tanger, 2019, p. 832-836. WOS:000539487400135 